\title{
PERBEDAAN TINGKAT DEPRESI ANTARA LANSIA DI PEDESAAN DAN PERKOTAAN
}

\author{
Tunjung Sri Yulianti' ${ }^{1}$ Anggit Ike Prascika²
}

\begin{abstract}
Elderly will fail maintaining a balance of physiological conditions, thereby increasing vulnerability to depression. Factors that influence is the socio-economic changes, social values, awareness among individuals and others. More urban environment is individualistic and socioeconomic pressures are higher, while rural areas have the educational background lower. The results showed not a few elderly people who returned to the village because they felt pressured by the situation in the city, the elderly should be alone in the house and no neighbors who could be invited to communicate, so it is difficult to be happy. But there are also elderly who live in the village reveal feeling depressed and showed signs of depression. Purpose of the study to determine the level of depression in the elderly in urban, rural and differences in the level of depression among the elderly who live in rural and urban areas.

Subjects were elderly who live in the village of Palur Sukoharjo and Kampung Sewu Surakarta. Methods of analytical study comparative research design. Measuring instrument used is the Geriatric Depression Scale. Test data normality using the Kolmogorov-Smirnov Test. Statistical test with independent $t$ test.

The results of the study obtained significancy value of t-test (two-tailed) 0.001 . Conclusion of research is significant difference in rates of depression among the elderly in urban and rural areas, the elderly in urban areas have higher levels of depression than elderly people in rural areas
\end{abstract}

Keywords: Elderly Depression Level, Rural, Urban

\section{PENDAHULUAN}

Salah satu indikator keberhasilan pembangunan adalah semakin meningkatnya usia harapan hidup penduduk. Dengan semakin meningkatnya usia harapan hidup penduduk, menyebabkan jumlah penduduk lanjut usia terus meningkat dari tahun ke tahun. Proporsi lansia di Indonesia telah mencapai 8,03 persen dari keseluruhan penduduk, sementara proporsi penduduk produktif 10-59 tahun terbesar jika dibandingkan kelompok umur lainnya. $\mathrm{Hal}$ ini menunjukkan bahwa Indonesia termasuk negara dengan struktur penduduk menuju tua (ageing population) (Susilo, Chamami, dan Handayani, 2014). Seseorang yang berada pada periode lanjut usia akan mengalami kegagalan untuk mempertahankan keseimbangan terhadap kondisi stress fisiologis. Hal tersebut secara tidak langsung berhubungan dengan penurunan daya kemampuan untuk hidup dan peningkatan kepekaan secara individual, sehingga kerentanan orang lanjut usia terhadap gangguan depresi meningkat. Peningkatan kerentanan terhadap gangguan depresi dapat dipengaruhi oleh beberapa faktor, antara lain faktor biologi dengan disfungsi neourotransmitter otak, efek farmakologi obat, faktor penyakit medis (kardiovaskular, diabetes, demensia, dan kelainan neurologi lain), gangguan kecemasanan, gangguan tidur, faktor kepribadian, faktor isolasi, faktor sosial dan lingkungan. Depresi pada lansia merupakan permasalahan kesehatan jiwa (mental health) yang serius dan 
komplek, tidak hanya dikarenakan aging process tetapi juga faktor lain yang sangat terkait. Sehingga dalam mencari penyebab depresi pada lansia harus dengan multiple approach (Aspiani, 2014).

Penelitian yang dilakukan oleh Bhayu, Ratep dan Westa (2014) tentang faktor yang mempengaruhi kejadian depresi pada lansia ditemukan hasil bahwa umur, jenis kelamin dan penyakit dasar merupakan faktor yang berpengaruh pada kejadian depresi. Sedangkan penelitiannya Muna, Arwani dan Purnomo (2013) menyatakan bahwa umur, jenis kelamin dan tingkat pendidikan berhubungan dengan kejadian depresi pada lansia. Menurut Darmojo dan Martono (2004) sebagaimana dikutip oleh Aspiani (2014) perubahan sosial ekonomi dan nilai sosial masyarakat. Pergeseran sistem keluarga dari extended family ke nuclear family akibat industrialisasi dan urbanisasi mengakibatkan lansia terpinggirkan. Budaya industrialisasi dengan sifat mandiri dan individualis menganggap lansia sebagai "trouble maker" dan menjadi beban sehingga langkah penyelesaiannya dengan menitipkan di panti. Kondisi ini tentu saja akan berpengaruh pada kejadian depresi pada lansia.

Penelitian yang dilakukan oleh Sari, Arneliwati dan Utami (2015) ditemukan hasil lansia yang tinggal di panti mempunyai tingkat depresi lebih tinggi daripada yang tinggal bersama keluarga. Meskipun begitu penelitian yang dilakukan oleh Pradnyandari dan Diniari (2013) menunjukkan hasil yang berbeda yaitu tidak ada perbedaan yang signifikan antara tingkat depresi lansia yang tinggal di panti wreda dan yang tinggal bersama keluarga. Faktor psikososial yaitu kepedulian antar individual, keadaan sosial ekonomi dan latar belakang pendidikan juga berpengaruh.
Lingkungan perkotaan lebih bersifat individualisme dan tekanan sosial ekonomi yang lebih tinggi dibandingkan dengan pedesaan, sedangkan pedesaan memiliki latar belakang pendidikan yang lebih rendah dibanding dengan perkotaan. Faktor biologis juga berpengaruh karena terdapat perbedaan kesadaran dan penanganan penyakit fisik pada lanjut usia.

Beberapa kejadian yang peneliti amati menunjukkan tidak sedikit lansia yang kembali atau mencari tempat tinggal di desa karena sering merasa tertekan dengan keadaan di kota, dimana setiap orang sibuk dengan pekerjaan masing-masing, sehingga lansia harus sendirian di rumah dan tidak ada teman atau tetangga yang bisa diajak berkomunikasi, lansia menjadi sukar untuk bisa senang. Namun ada juga beberapa lansia yang tinggal di desa mengungkapkan perasaan tertekan dan menunjukkan tanda depresi ringan seperti kehilangan minat dan kegembiraan serta sulit konsentrasi. Penelitian yang dilakukan oleh dilakukan Siboro dan Rusdi (2012) menunjukkan hasil bahwa pola komunikasi keluarga yang fungsional semakin menurunkan tingkat depresi pada lansia. Penelitian terkait dengan perbedaan tingkat depresi pada lansia di wilayah pedesaaan dan perkotaan belum pernah dilakukan, sehingga mendorong peneliti untuk melakukan penelitian dengan judul "Perbedaan Tingkat Depresi antara Lansia yang Tinggal di Pedesaan dan Perkotaan ".

\section{TUJUAN PENELITIAN}

Untuk mengetahui tingkat depresi pada lansia di perkotaan, di pedesaan dan untuk mengetahui perbedaan tingkat depresi antara lansia yang tinggal di pedesaan dan perkotaan di wilayah Desa Palur 
Sukoharjo dan Kampung Sewu Kotamadya Surakarta.

\section{DESAIN PENELITIAN}

Desain penelitian ini adalah penelitian analitik dengan rancangan penelitian komparasi untuk mengetahui perbedaan tingkat depresi antara lansia yang tinggal di pedesaan dengan di perkotaan. Alat ukur yang digunakan untuk tingkat depresi pada lansia adalah Geriatric Depression Scale. Uji normalitas data menggunakan KolmogorovSmirnov Test. Uji statistik yang digunakan adalah Independen $t$ test.

\section{POPULASI, SAMPEL, DAN TEHNIK SAMPLING}

Populasi penelitian ini adalah seluruh lansia yang tinggal di Desa Palur Karanganyar dan Kampung Sewu Surakarta. Sampel penelitian adalah lansia Desa Palur dan Kampung Sewu yang sesuai dengan kriteria inklusi sejumlah 80 orang lansia. Sampel diambil dengan menggunakan teknik purposive sampling.

\section{HASIL PENELITIAN}

Penelitian ini dilakukan pada bulan Mei sampai dengan Agustus 2016.

1. Karakteristik Responden Tabel 1.

Distribusi Frekuensi Karakteristik Responden

\begin{tabular}{cccccc}
\hline \multirow{2}{*}{$\begin{array}{c}\text { Karakte- } \\
\text { ristik }\end{array}$} & \multirow{2}{*}{ Kate gori } & \multicolumn{2}{c}{ Desa } & \multicolumn{2}{c}{ Kp. Sewu } \\
\cline { 3 - 6 } & & $\mathrm{n}$ & $\mathrm{f}$ & $\mathrm{n}$ & $\mathrm{f}$ \\
\hline Jenis & Laki-laki & 11 & 28 & 18 & 45 \\
Kelamin & Perempuan & 29 & 72 & 22 & 55 \\
Tingkat & SD & 32 & 80 & 15 & 38 \\
Pendidik & SMP & 8 & 20 & 13 & 32 \\
an & SMA & 0 & 0 & 11 & 28 \\
& PT & 0 & 0 & 1 & 2 \\
Status & Bekerja & 12 & 30 & 17 & 43 \\
Bekerja & Tidak & 28 & 70 & 23 & 57 \\
Pasangan & Ada & 33 & 83 & 32 & 80 \\
Hidup & Tidak Ada & 7 & 17 & 8 & 20 \\
Riwayat & Ada & 10 & 25 & 17 & 43 \\
Penyakit & Tidak Ada & 30 & 75 & 23 & 57 \\
\hline
\end{tabular}

Dari tabel di atas dapat diketahui jenis kelamin terbanyak pada kedua kelompok adalah lansia perempuan, tingkat pendidikan lansia di perkotaan mulai dari SD sampai perguruan tinggi tetapi di pedesaan hanya SD dan SMP. Sebagian besar lansia di kedua kelompok tidak bekerja, masih mempunyai pasangan hidup dan tidak mempunyai riwayat penyakit.

2. Perbedaaan Tingkat Depresi antara Lansia di Pedesaan dan Perkotaan

Tabel 2.

Perbedaan Tingkat Depresi antara Lansia di Pedesaan (Desa Palur) dan Perkotaan (Kampung Sewu)

\begin{tabular}{|c|c|c|c|c|}
\hline \multirow{2}{*}{$\begin{array}{l}\text { Tingkat } \\
\text { Depresi }\end{array}$} & \multicolumn{2}{|c|}{ Desa Palur } & \multicolumn{2}{|c|}{ Kampung Sewu } \\
\hline & $f$ & $\%$ & $f$ & $\%$ \\
\hline Tidak Ada & 32 & 80 & 17 & 43 \\
\hline Sedang & 8 & 20 & 16 & 40 \\
\hline Berat & 0 & 0 & 7 & 17 \\
\hline Rata-Rata & 7,68 & & 12,45 & 100 \\
\hline
\end{tabular}

Dari tabel di atas diperoleh informasi bahwa sebagian besar responden pada kedua kelompok berada pada tingkat tidak ada depresi. Pada kelompok lansia di perkotaan terdapat 7 responden (17\%) yang berada pada tingkat depresi berat, sedangkan pada kelompok lansia di pedesaan tidak ada yang berada pada tingkat depresi berat. Rata-rata tingkat depresi pada lansia di pedesaan adalah tidak ada depresi dengan nilai Mean 7,68. Sedangkan rata-rata tingkat depresi pada lansia di perkotaan adalah depresi sedang dengan nilai Mean 12.45. 
3. Hasil Uji Statistik

Tabel 3.

Tabel Statistik Uji Independent t-test

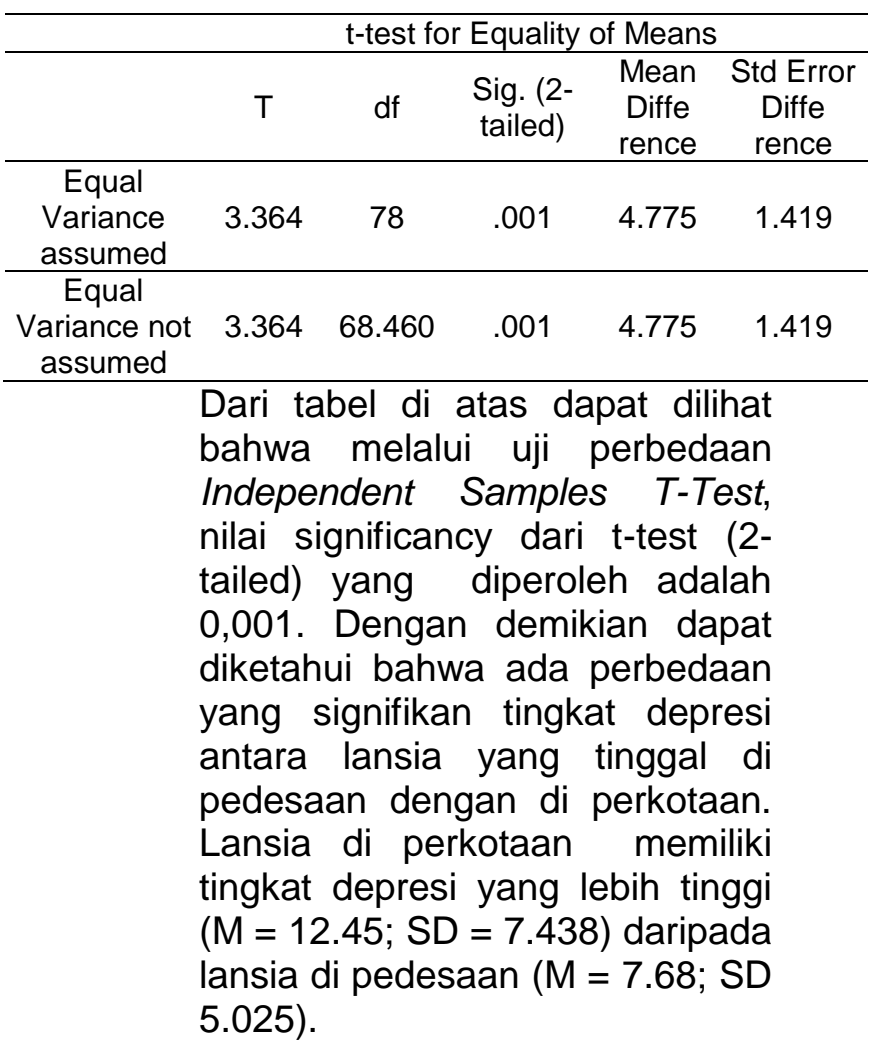

\section{PEMBAHASAN}

1. Tingkat Depresi Pada Lansia di Pedesaan (Desa Palur)

Berdasarkan data responden, diperoleh informasi bahwa sebagian besar responden yaitu 32 orang $(80 \%)$ berada pada kategori tidak ada depresi. Sedangkan 8 orang (20\%) mengalami depresi sedang.

Menua bukanlah suatu penyakit, tetapi merupakan proses yang berangsur-angsur mengakibatkan perubahan yang kumulatif, merupakan proses menurunnya daya tahan tubuh dalam menghadapi rangsangan dari dalam dan luar tubuh yang berakhir dangan kematian. (Nugroho, 2008) Lansia yang tidak bisa menerima perubahan yang terkait dengan proses menua yang dialaminya tersebut menyebabkan perubahan psikologis dan sosial. Hal tersebut sebagaimana dipaparkan Samiun (2006) dalam Aspiani (2014) depresi pada lansia adalah dampak negatif kejadian penurunan fungsi tubuh dan perubahan yang terjadi terutama perubahan psikososial dan kehilangan kebutuhan afeksional misalnya kehilangan orang yang dicintai, pekerjaan, jabatan dan sejenisnya.

Apabila dicermati dari data yang diperoleh dari kelompok lansia di pedesaan (Desa Palur) terdapat 8 orang lansia yang mengalami depresi sedang. Dari 8 orang lansia tersebut 7 orang diantaranya tidak bekerja. Kehilangan pekerjaan akibat memasuki masa pensiun ataupun karena penurunan produktifitas kerja akibat penurunan fungsi kesehatan tentu saja akan berdampak pada sumber finansial keluarga, hal ini yang bisa menjadi faktor penyebab depresi pada lansia. Hal ini sesuai dengan paparan Maryam, et al. (2008), bahwa nilai seseorang sering diukur melalui produktifitasnya dan identitasnya dikaitkan dengan perasaan dan pekerjaan. Bila mengalami pensiun (purnatugas) seseorang akan mengalami kehilangan antara lain: kehilangan finansial (pendapatan berkurang), kehilangan status (dulu mempunyai jabatan/posisi yang cukup tinggi, lengkap dengan semua fasilitas), kehilangan teman/kenalan atau rekan, kehilangan pekerjaan/ kegiatan. Sedangkan faktor resiko terjadinya masalah kesehatan jiwa pada lansia meliputi : kesehatan fisik yang buruk, perpisahan dengan pasangan, perumahan dan transportasi yang tidak memadai, sumber finansial berkurang dan dukungan sosial berkurang. 
Data di atas juga menunjukkan persentase terbanyak di Desa Palur adalah lansia yang tidak ada depresi (80\%). Hal ini bisa dikaitkan dengan karakteristik kehidupan di desa dimana menurut Arfiani et al. (2014) dalam masyarakat desa corak kehidupan bersifat gemein-schaft yaitu diikat oleh kekeluargaan yang kuat, penduduk desa merupakan masyarakat yang bersifat face to face group artinya saling mengenal antar sesama warga. Lansia di pedesaan mempunyai teman atau tetangga yang bisa diajak berkomunikasi. Sedangkan sebagian lansia yang lain dapat menghibur diri dengan bertani, berkebun atau berternak di lahan sendiri. Kondisi ini bisa meningkatkan kepercayaan diri lansia karena mereka merasa masih bisa berguna bagi hidupnya sendiri maupun keluarga. Banyaknya orang yaitu keluarga dan tetangga di sekitar yang bisa diajak berkomunikasi memungkinkan lansia tidak mengalami kesepian, tersisihkan dan terbengkalai sehingga menurunkan resiko terjadinya masalah kesehatan jiwa pada lansia. Hal ini sesuai dengan hasil penelitian yang dilakukan oleh Siboro dan Rusdi (2012) yang menunjukkan hasil bahwa pola komunikasi keluarga yang fungsional semakin menurunkan tingkat depresi pada lansia.

Adapun bila dilihat dari data keberadaan pasangan hidup terdapat $83 \%$ lansia di Desa Palur masih mempunyai pasangan, dan terkait dengan riwayat penyakit diperoleh data $75 \%$ lansia tidak memiliki riwayat penyakit. Kondisi yang demikian memberikan kontribusi yang positif terhadap penurunan resiko depresi mengingat pasangan hidup dan kondisi fisiologis tubuh menjadi salah satu faktor resiko.
Hal ini sesuai dengan paparan Maryam, et al. (2008), bahwa faktor resiko terjadinya masalah kesehatan jiwa pada lansia meliputi : kesehatan fisik yang buruk, perpisahan dengan pasangan, perumahan dan transportasi yang tidak memadai, sumber finansial berkurang dan dukungan sosial berkurang.

2. Tingkat Depresi Pada Lansia di Perkotaan (Kampung Sewu)

Berdasarkan data responden, diperoleh informasi bahwa jumlah responden yang tidak mengalami depresi dan yang depresi sedang hampir sama yaitu 17 orang (43\%) berada pada kategori tidak ada depresi dan 16 orang (40\%) pada kategori depresi sedang. Sedangkan 7 orang (17\%) berada pada kategori depresi berat. Dari data karakteristik responden dapat diketahui bahwa dari 7 responden yang mengalami depresi berat tersebut 6 responden diantaranya tidak bekerja, dan dari 6 responden tersebut 5 diantaranya mempunyai penyakit. Menurut Aspiani (2014) seseorang yang berada pada periode lanjut usia akan mengalami kegagalan untuk mempertahankan keseimbangan terhadap kondisi stres fisiologis. Hal tersebut secara tidak langsung berhubungan dengan penurunan daya kemampuan untuk hidup dan peningkatan kepekaan secara individual, sehingga kerentanan orang lanjut usia terhadap gangguan depresi meningkat. Peningkatan kerentanan terhadap gangguan depresi dapat dipengaruhi oleh beberapa faktor, antara lain faktor biologi dengan disfungsi neurotransmitter otak, efek farmakologi obat, faktor penyakit medis (kardiovaskular, diabetes, demensia, dan kelainan neurologi lain), gangguan kecemasan, gangguan tidur, faktor 
kepribadian, faktor isolasi, faktor sosial dan lingkungan.

Apabila dicermati lebih lanjut, 7 responden yang mengalami depresi berat, 5 orang diantaranya mempunyai riwayat penyakit Kondisi ini sesuai dengan penelitian yang dilakukan oleh Bhayu, Ratep dan Westa (2014) tentang faktor yang mempengaruhi kejadian depresi pada lansia dimana ditemukan hasil bahwa umur, jenis kelamin dan penyakit dasar merupakan faktor yang berpengaruh pada kejadian depresi. Menurut Maryam, et al. (2008), faktor resiko terjadinya masalah kesehatan jiwa pada lansia meliputi : kesehatan fisik yang buruk, perpisahan dengan pasangan, perumahan dan transportasi yang tidak memadahi, serta sumber finansial berkurang. Sedangkan menurut Yosep dan Sutini (2014) depresi disebabkan oleh banyak faktor antara lain : herediter dan genetik, konstitusi, kepribadian pramorbid, fisik, psikobiologi, neurologi, biokimia dalam tubuh, keseimbangan elektolit, dan sebagainya. Kondisi yang sama juga ditemukan pada lansia yang masuk dalam kategori depresi sedang. Dari 16 responden yang masuk dalam kategori depresi sedang, 9 orang diantaranya tidak bekerja dan 7 orang diantaranya mempunyai riwayat penyakit.

Adapun bila dilihat dari data keberadaan pasangan hidup terdapat $80 \%$ lansia di Kampung Sewu masih mempunyai pasangan, dan terkait dengan riwayat penyakit diperoleh data $57 \%$ lansia tidak memiliki riwayat penyakit. Keberadaan pasangan hidup pada lansia di Kampung Sewu bisa memberikan kontribusi yang positif terhadap penurunan resiko depresi pada lansia, karena sesuai dengan paparan dari Maryam, et al. (2008), faktor resiko terjadinya masalah kesehatan jiwa pada lansia meliputi : kesehatan fisik yang buruk, perpisahan dengan pasangan, perumahan dan transportasi yang tidak memadai, sumber finansial berkurang, dukungan sosial berkurang.

3. Perbedaan Tingkat Depresi antara Lansia di Pedesaan dan Perkotaan.

Melalui uji perbedaan Independent Samples T-Test dapat dilinat bahwa nilai significancy dari t-test (2-tailed) yang diperoleh adalah 0,001. Dengan demikian dapat diketahui bahwa ada perbedaan tingkat depresi yang signifikan antara lansia di perkotaan dan pedesaan. Dari analisa univariat diperoleh perbedaan rata-rata tingkat depresi pada kedua kelompok responden. Lansia di pedesaan rata-rata berada pada kategori tidak ada depresi (Mean : 7,68) sedangkan di perkotaan rata-rata mengalami depresi sedang (Mean : 12.45).

Menurut Darmojo dan Martono (2004) sebagaimana dikutip oleh Aspiani (2014) perubahan sosial ekonomi dan nilai sosial masyarakat, mengakibatkan kecenderungan lansia tersisihkan dan terbengkalai, tidak mendapatkan perawatan serta banyak yang memilih untuk menempatkannya di panti lansia. Pergeseran sistem keluarga dari extended family ke nuclear family akibat industrialisasi dan urbanisasi mengakibatkan lansia terpinggirkan. Budaya industrialisasi dengan sifat mandiri dan individualis menganggap lansia sebagai trouble maker dan menjadi beban sehingga langkah penyelesaiannya dengan menitipkan di panti. Kondisi ini 
memungkinkan akan berpengaruh pada kejadian depresi pada lansia.

Demikian halnya yang bisa diamati pada wilayah Kampung Sewu. Dimana Kampung Sewu merupakan salah satu wilayah di kotamadya Surakarta dengan karakteristik daerah perkotaan, dimana perbandingan lahan dan manusia lebih sempit, industrialisasi terlihat dari banyaknya bangunan pabrik, dan warga Kampung Sewu banyak yang bekerja di pabrik atau perusahaan dengan ritme kerja yang cukup padat dan menyita waktu. Kondisi ini memungkinkan untuk meningkatkan sifat individualistik dan menurunkan kepedulian sosial warganya. Seperti halnya penelitian yang dilakukan oleh Pradnyandari dan Diniari (2013) yang menunjukkan hasil tidak ada perbedaan yang signifikan antara tingkat depresi lansia yang tinggal di panti wreda dan yang tinggal bersama keluarga. Karena faktor psikososial yaitu kepedulian antar individual, keadaan sosial ekonomi dan latar belakang pendidikan juga berpengaruh.

Menurut Samiun (2006) dalam Aspiani (2014) depresi pada lansia adalah dampak negatif kejadian penurunan fungsi tubuh dan perubahan yang terjadi terutama perubahan psikososial dan kehilangan kebutuhan afeksional misalnya kehilangan orang yang dicintai, pekerjaan, jabatan dan sejenisnya. Faktor psikososial yang berpengaruh pada kejadian depresi lansia yaitu kepedulian antar individu, keadaan sosial ekonomi dan latar belakang pendidikan. Lingkungan perkotaan lebih bersifat individualisme dan tekanan sosial ekonomi yang lebih tinggi dibandingkan dengan pedesaan, di kota setiap orang sibuk dengan pekerjaan masing-masing, sehingga banyak lansia harus sendirian di rumah dan tidak ada teman atau tetangga yang bisa diajak berkomunikasi, lansia menjadi sukar untuk bisa senang. Demikian halnya yang terjadi pada lansia di Kampung Sewu. Karakteristik masyarakat perkotaan yang sibuk dengan pekerjaannya masing-masing menurunkan frekuensi komunikasi antar warga. Sehingga bagi lansia yang tidak bekerja akan lebih merasa kesepian. Sementara itu lansia yang masih bekerja pun dihadapkan pada kondisi persaingan kerja yang cukup ketat sehingga membutuhkan konsentrasi yang lebih tinggi dan menimbulkan tekanan untuk memenuhi kebutuhan sosial ekonomi pada lansia. Kondisi tersebut cenderung menyokong kejadian depresi lansia.

Hal ini sebagaimana dipaparkan oleh Samiun (2006) dalam Aspiani (2014) bahwa depresi pada lansia merupakan perpaduan interaksi yang unik dari berkurangnya interaksi sosial, kesepian, masalah sosial ekonomi, perasaan rendah diri karena penurunan kemampuan, kemandirian dan penurunan fungsi tubuh, kesedihan ditinggal orang yang dicintai, faktor kepribadian, genetik dan faktor biologi yaitu penurunan neuronneuron dan neurotransmitter di otak. Sedangkan menurut Arfiani et al. (2014), pedesaan memiliki latar belakang pendidikan yang lebih rendah dibanding dengan perkotaan tetapi pedesaan masih menganut hubungan kekerabatan yang kuat, corak kehidupan bersifat "gemein-schaft" yaitu diikat oleh kekeluargaan yang kuat, penduduk desa merupakan masyarakat yang bersifat "face to face group" artinya saling 
mengenal antar sesama warga. Sifat gotong royong masih cukup tampak dalam kehidupan seharihari, perbandingan lahan dengan manusia masih cukup besar dan lapangan kerja didominasi sektor agraris. Dengan kondisi yang demikian lansia di desa masih dapat berkomunikasi dan berinteraksi dengan keluarga dan lingkungan sekitar.

Demikian halnya yang terjadi pada kelompok lansia di Desa Palur. Pendidikan mereka terbanyak adalah SD (80\%) kemudian SMP (20\%). Tidak ada yang berpendidikan SMA maupun Perguruan Tinggi. Meskipun tingkat pendidikannya rendah tetapi dari hasil data tentang tingkat depresi sebagian besar lansia $(80 \%)$ berada pada kategori tidak ada depresi. Hal tersebut tidak bisa dilepaskan dari situasi atau karakteristik desa sebagaimana telah dipaparkan sebelumnya. Desa Palur kecamatan Mojolaban Kabupaten Sukoharjo adalah daerah dengan wilayah cukup luas, banyak masyarakat yang hidup dengan bertani dan karakteristik pedesaan masih terlihat di wilayah tersebut dimana hubungan kekerabatan masih kuat dan masyarakat masih memegang nilai tradisi dan budaya setempat. Kemudahan berkomunikasi dan berinteraksi dengan keluarga dan lingkungan sekitar, serta sebagian lansia dapat menghibur diri dengan bertani, berkebun atau berternak di lahan sendiri. Hal-hal tersebut dapat berkontribusi terhadap penurunan tingkat depresi pada lansia.

Kondisi ini sejalan dengan penelitian yang dilakukan oleh Siboro dan Rusdi (2012) yang menunjukkan hasil bahwa pola komunikasi keluarga yang fungsional semakin menurunkan tingkat depresi pada lansia. Dengan variabel penelitian yang agak berbeda, penelitian yang dilakukan oleh Sari, Arneliwati dan Utami (2015) memperoleh hasil lansia yang tinggal di panti mempunyai tingkat depresi lebih tinggi daripada yang tinggal bersama keluarga. Hal ini menunjukkan bahwa komunikasi, kedekatan dan kekerabatan berpengaruh pada penurunan kejadian depresi lansia. Dimana di masyarakat pedesaan memungkinkan lansia untuk memperoleh dukungan meskipun tidak selalu tinggal dengan keluarga tetapi lansia mendapatkan dukungan dari lingkungan sekitar, mempunyai kesempatan untuk berinteraksi dan menyibukkan diri dengan aktifitas beternak dan bertani di lahan sendiri.

\section{KESIMPULAN}

1. Tingkat depresi lansia di wilayah perkotaan (Kampung Sewu) adalah 17 responden (43\%) pada tingkat tidak ada depresi, 16 responden (40\%) pada tingkat depresi sedang dan 7 responden $(17 \%)$ pada tingkat depresi berat.

2. Tingkat depresi lansia di wilayah pedesaan (Desa Palur) adalah 32 responden $(80 \%)$ pada tingkat tidak ada depresi, 8 responden (20\%) pada tingkat depresi sedang dan tidak ada lansia yang mengalami depresi berat.

3. Melalui uji perbedaan Independent Samples T-Test, terbukti ada perbedaan tingkat depresi yang signifikan antara lansia di perkotaan dan pedesaan. Lansia di perkotaan memiliki tingkat depresi yang lebih tinggi $(M=12.45)$ daripada lansia di pedesaan $(M=7.68)$. 


\section{SARAN}

1. Bagi masyarakat yang tinggal di perkotaan terutama keluarga yang memiliki lansia disarankan untuk mempertahankan komunikasi dan interaksi yang positif dengan lansia dan memfasilitasi aktivitas-aktivitas yang meningkatkan harga diri.

2. Bagi peneliti selanjutnya diharapkan meneliti perbedaan tingkat depresi lansia di pedesaan dan perkotaan dilihat dari faktor-faktor yang menyebabkan depresi.

\section{DAFTAR PUSTAKA}

Arfiani, G., et al. 2015. Detik-detik Ujian Nasional Geografi. Intan Pariwara, Klaten.

Ariani, A. P. 2014. Aplikasi Metodologi Penelitian Kebidanan dan Kesehatan Reproduksi. Nuha Medika, Yogyakarta.

Aspiani, R. Y. 2014. Buku Ajar Asuhan Keperawatan Gerontik. Jilid 1. EGC, Jakarta.

. 2014. Buku Ajar Asuhan Keperawatan Gerontik. Jilid 2. EGC, Jakarta.

Azizah, L. M. 2011. Keperawatan Lanjut Usia. Graha IImu, Yogyakarta.

Bhayu, IGM A., Ratep, N. dan Wayan, W. 2014. Gambaran Faktor-Faktor Yang Mempengaruhi Tingkat Depresi Pada Lanjut Usia Di Wilayah Kerja Puskesmas Kubu II. http://ojs.unud.ac.id/index.php/ eum/article/view/12599. Diakses tanggal 14 April 2016.

Hidayat, A. A. 2008. Riset Keperawatan dan Tehnik Penulisan IImiah. Salemba, Medika Jakarta. . 2009. Metodologi Penelitian Keperawatan dan Teknik Analisis Data. Salemba Medika, Jakarta.
Hawari, D. 2006. Manajemen Setres Cemas dan Depresi. Fakultas Kedokteran Universitas Indonesia, Jakarta.

Maryam, S., et al. 2008. Mengenal Usia Lanjut dan Perawatannya. Salemba Medika, Jakarta.

Muna, N., Arwani dan Purnomo. 2013. Hubungan Antara Karakteristik Dengan Kejadian Depresi Pada Lansia Di Panti Werda Pelkris Pengayoman Kota Semarang. http://download.portalgaruda.o rg/article.php?article $=183482 \&$ val=6378. Diakses tanggal 14 April 2016.

Nugroho, W. 2008. Keperawatan Gerontik dan Geriatrik. ed. 3. EGC, Jakarta.

Pradnyandari, N. K. D. dan Ni Ketut S. Diniari, N.K.S. 2013. Perbandingan Kejadian Dan Status Depresi Lansia Yang Tinggal Bersama Keluarga Dengan Yang Tinggal Di Panti Sosial Tresna Werdha Wana Seraya Denpasar Bali. http://ojs.unud.ac.id/index.php/ eum/article/view/11953.

Diakses tanggal 14 April 2016.

Riwidikdo, H. 2009. Statistik Kesehatan. Citra Medika, Yogyakarta.

Sari, R., Arneliawati dan Utami, S. 2015. Perbedaan Tingkat Depresi Antara Lansia Yang Tinggal di PSTW Dengan Lansia Yang Tinggal Di Tengah Keluarga. http://jom.unri.ac.id/index.php/ JOMPSIK/article/view/8318. Diakses tanggal 14 April 2016. Siboro, E.N. dan Rusdi, I. 2012. Pola Komunikasi Keluarga Dan Tingkat Depresi Lansia Di Kelurahan Padang Bulan Medan.

http://download.portalgaruda.o rg/article.php?article $=59065 \& \mathrm{v}$ al=4132. Diakses tanggal 14 April 2016. 
••KOsคเn״ JIK. Vol. 4 No. 2 September 2016

Susilo, D., Chamami, A. dan Handayani, N.B. Statistik Penduduk Lanjut Usia Tahun 2014. 2015. Badan Pusat Statistik, Jakarta.

Suyanto. 2011. Metodologi dan Aplikasi Penelitian Keperawatan. Nuha Medika, Yogyakarta.

Yosep, I. dan Sutini, T. 2007. Buku Ajar Keperawatan Jiwa. Refika Aditama, Bandung.

${ }^{1}$ Dosen Akper Panti Kosala

Surakarta

${ }^{2}$ Mahasiswa Akper Panti Kosala

Surakarta 